\title{
Mutations in the Growth Hormone Releasing Hormone Receptor
}

\author{
Gerhard Baumann \\ Center for Endocrinology, Metabolism and Molecular Medicine, Northwestern University \\ Medical School, Chicago, USA
}

Growth hormone (GH) secretion is controlled by growth hormone releasing hormone (GHRH), somatostatin, and ghrelin or a similar GH secretagogue. These hypophysiotropic peptides interact with specific receptors in the pituitary. Until recently, these concepts have been primarily supported by pharmacological evidence. The discovery of naturally occurring mutations in the GHRH receptor has illustrated the paramount importance of the GHRH system in the proper functioning of the $\mathrm{GH}$ axis.

In 1976, the little mouse was discovered in a colony at the Jackson laboratories (1). Extensive studies indicated that its small body size was caused by GH deficiency. This dwarf phenotype was inherited in an autosomal recessive manner, and linkage studies placed the defect on chromosome 6. GH deficiency was isolated, and other pituitary hormones were essentially normal. During the ensuing years the little mouse phenotype was characterized, but the genetic basis remained unknown. When GHRH became available, the little mouse was found to be unresponsive to GHRH, both in vivo with $\mathrm{GH}$ secretion and in vitro with GH release or cAMP generation $(2,3)$. This observation gave rise to the idea that there was something wrong with the GHRH receptor or its immediate downstream signaling mechanisms. The cloning and characterization of the GHRH receptor (GHRH-R) (4-6) made it possible to test this hypothesis. The GHRH-R belongs to group B of the serpentine, G-

Correspondence to: Prof. Gerhard Baumann, 303 E. Chicago Avenue, Chicago, IL 60611, USA protein coupled receptor family (7). In short order, the little mouse was found to harbor a missense mutation (D60G) in the proximal extracellular domain of the GHRH-R $(8,9)$. This is due to a single base change $(A \rightarrow G)$ in codon 60 , and the mutation was termed "little" or lit. The affected aspartate is highly conserved among GHRH-Rs in other species and in all receptors of the same class. It was therefore believed to be functionally important. Only recently, however, has the reason for the dysfunction of the lit mutation been fully elucidated. The mutant receptor is synthesized and displayed at the cell surface, but it is unable to bind GHRH and hence cannot transmit a GHRH signal (10).

The human counterpart of the little mouse was only recently discovered. This story started unexpectedly when a newspaper article in Karachi, Pakistan, appeared in 1994, with the title "The Dwarfs of Sindh" (Sindh is the southernmost province of Pakistan). The article described a cluster of dwarfs in two villages in the lower Indus valley. My colleague Dr. Maheshwari, then residing in Karachi, contacted me, asking whether we could help him investigate this phenomenon. He verified the newspaper story and found what looked like a familial type of proportionate dwarfism in a highly consanguineous extended kindred. During an expedition to the region, we collected pedigree, general medical, epidemiological, anthropological and endocrinological information, as well as blood, DNA and RNA. Pituitary stimulation tests, IGF generation tests, and hand X-rays were obtained. 
Analysis of the extensive data collected in the field showed that dwarfism was proportionate in 18 affected individuals found, that all were below age 30, and that genetic transmission was autosomal recessive. Parents were of normal stature. All affected patients had isolated GH deficiency of a severe degree, but responded well to exogenous GH administration with IGF-1 and IGF binding protein 3 generation. The findings have been reported in detail $(11,12)$. Given the $\mathrm{GH}$ deficiency, several features were unusual: 1) there was no or only minimal dysmorphism, unlike that seen in other types of GH deficiency or GH insensitivity; 2) there was relative microcephaly (4 SDS), which rendered the patients more proportionate than what is seen in other types of GH deficiency; 3) there was no known history of hypoglycemia. Given the familial and most likely genetic nature of this syndrome, we first sequenced the GH-N gene its entirety, but found no abnormality. We then used linkage analysis with a candidate gene approach, probing the loci of several potential genes that might be defective. This yielded a high lod score for a locus near the GHRH-R gene on chromosome 7p14. Sequencing of that gene showed a $\mathrm{G}$ to $\mathrm{T}$ transversion in a region coding for the extracellular part of the GHRH-R. This creates a new stop codon at residue 72 and predicts a truncation about 10 amino acid residues downstream from where the lit mutation is located in the mouse. This truncated receptor would lack virtually all its functional domains; it is most likely not expressed, but degraded in the endoplasmic reticulum. All affected patients were homozygous for the mutation; parents were heterozygous. Based on this, we concluded that Dwarfism of Sindh was due to a severely inactivating mutation in the GHRH-R and thus represented the human homologue of the little mouse. While this work was in its final stages, a publication by Wajnrajch et al. appeared, describing two siblings with a very similar phenotype and the same mutation (13). Interestingly, that family, although living in New
York, was of Indian origin. The patients had been treated with GH and responded well with sustained growth acceleration. Subsequently, Netchine et al. reported two additional patients, of Sri Lankan origin, with the identical mutation and phenotype (14). They had also been treated with GH and responded well in terms of somatic growth. Affected patients have significant pituitary hypoplasia, with pituitary volumes of $30-50 \%$ of normal $(14,15)$. This is in agreement with somatotroph hypoplasia in the little mouse $(9,16)$. To date, a total of 23 patients with the Sindh mutation are known. Of these, 19 (83\%) are male, a finding that is unexplained. There is no known relationship between the three affected kindreds; although all are from the Indian subcontinent, they are from widely disparate populations that differ in cultural, linguistic and geographic terms. Neveretheless, preliminary data using haplotype analysis suggest that the three kindreds are very distantly related, with a possible founder mutation several hundred years ago (17). In that case, it is not clear why this highly penetrant and seemingly unmistakable phenotype has not been observed before.

In the mid-1990s, a large group of dwarfed people came to attention in the town of Itabaianinha, in Northeastern Brazil. Two Brazilian groups, in conjunction with investigators in the United States, had been studying these people, determined that they were $\mathrm{GH}$ deficient, but the genetic basis of their short stature remained unknown. The GH-N gene had been found to be normal. The phenotype was very similar to that of the Sindhi dwarfs, with severe postnatal growth retardation, only mild dysmorphic features, no history of hypoglycemia, and normal-statured parents. The genomic characterization of the GHRH-R gene (18) permitted the discovery of a point mutation in the splice donor site of intron $1\left(\mathrm{~g}^{+1} \rightarrow \mathrm{a}\right)$ which completely tracked with the dwarf phenotype (19). This mutation is believed to cause readthrough into intron 1 , with sequence deviation within the 
signal peptide and premature termination upstream of the mature GHRH-R. The functional result is virtually total absence of the GHRH-R protein, functionally identical to the Sindh mutation. The Brazilian kindred is very large, with 105 affected patients known, of whom 80 are alive. The affected patients span three generations, with the oldest person in her 80s. Their phenotype is virtually identical to the Sindh population, including anthropometric data, biochemical parameters, and pituitary hypoplasia (19-21). The biochemical phenotype of heterozygotes also shows an intermediate pattern. The large size of the population allowed the unequivocal conclusion that the height of heterozygous members is statistically no different from the homozygous wild type relatives-a conclusion that could not be statistically proven in the Sindhi population because of its smaller size. One difference is the absence of hypotension, which was found in the Sindhis, but not observed in the Brazilians. However, hypotension is not believed to be a consequence of GHRH-R deficiency, but rather another co-inherited trait resulting from consanguinity (12). This interpretation is corroborated by the absence of hypotension in Itabaianinha patients.

Recently, additional instances of GHRH-R mutations have been described. Salvatori et al screened about 30 families known to have members with GH deficiency type IB and found GHRH-R mutations in 3 families (22). Homozygous missense mutations were found in transmembrane helix $1(\mathrm{~L} 144 \mathrm{H})$ in a family from Spain and in transmembrane helix 3 (A222E) in a Pakistani family residing in Saudi Arabia. A compound heterozygous patient from the United States harbored the above-mentioned L144H mutation in addition to a F242C mutation in transmembrane domain 4. The precise mechanism for receptor dysfunction caused by these missense mutations is not clear. Transmembrane domains are known to be involved in GHRH binding (23); it is also possible that the mutations disrupt helix formation, with resulting misfolding and instability of the protein. It should also be noted that the involved residues are conserved among GHRH receptors. Additional explanations are possible, but functional studies will be required to address these questions. It is also not clear from the limited data available whether GH deficiency resulting from these missense mutations is as severe as that in the Sindhi and Brazilian populations.

Finally, Horikawa and coworkers in Japan reported a boy with isolated GH deficiency and growth failure who was homozygous for a 4 base deletion (del 1121-1124) in transmembrane helix 7 (24). This mutation causes not only a frameshift and a premature truncation in transmembrane helix 7, but also disrupts the folding of helix 7 . The mutant GHRH-R lacks the entire intracellular domain which presumably plays a role in G-protein coupling. The mutant receptor, when expressed, failed to activate cAMP accumulation in response to GHRH (24).

Gain of function mutations in the GHRH-R have been extensively sought as a potential molecular basis for somatotrope adenomas and acromegaly. However, with one possible exception, this search has been largely fruitless. In a preliminary report, Petersenn et al. described two mutations in the GHRH-R in two somatotroph tumors which, when expressed, exhibited enhanced cAMP accumulation (25). Full description of these findings is awaited.

In summary, a total of 7 loss of function mutations have been described to date in the GHRH-R (Table 1). Most are point mutations and one is a $4 \mathrm{bp}$ deletion; they are spread throughout the GHRH-R receptor gene. They include one nonsense, one splice site, one frameshift/small deletion, and four missense mutations. Among the latter, only one has been mechanistically elucidated: the little mutation inactivates GHRH binding. All cause isolated GH deficiency, with severe postnatal growth failure and dwarfism. Special features are relative microcephaly, 
Table 1. Inactivating mutations in the GHRH receptor

\begin{tabular}{lclll}
\hline Type & Base change & Location & Consequence & Name \\
\hline Nonsense & & & & \\
Splice site & $\mathrm{G} \rightarrow \mathrm{T}$ & Exon 3 & Glu72X & Sindh \\
& & & & \\
Missense & $\mathrm{IVSg}^{+1} \rightarrow \mathrm{a}$ & Intron 1 & readthrough/Stop & Brazil \\
& $\mathrm{A} \rightarrow \mathrm{G}$ & Exon 3 & Asp60Gly & Little (mouse) \\
& $\mathrm{T} \rightarrow \mathrm{A}$ & Exon 5 & Leu144His & \\
& $\mathrm{C} \rightarrow \mathrm{A}$ & Exon 7 & Ala222Glu & \\
$\mathrm{T} \rightarrow \mathrm{G}$ & Exon 7 & Phe242Cys & \\
Deletion/Frameshift & & & \\
& $\Delta 4$ & Exon 12 & frameshift/Stop & \\
& & &
\end{tabular}

pituitary (somatotroph) hypoplasia, relative absence of dysmorphism typical of other types of GH deficiency or GH resistance, lack of microphallus, and apparent absence of hypoglycemia.

\section{Acknowledgements}

This study is supported in part by grants from the National Science Foundation and the Department of Veterans Affairs.

\section{References}

1. Eicher EM, Beamer WG. Inherited ateliotic dwarfism in mice. Characteristics of the mutation, little, on chromosome 6. J Hered 1976; 67: 87-91.

2. Clark RG, Robinson IC. Effects of a fragment of human growth hormone-releasing factor in normal and 'Little' mice. J Endocrinol 1985; 106: $1-5$.

3. Jansson JO, Downs TR, Beamer WG, Frohman LA. Receptor-associated resistance to growth hormone-releasing factor in dwarf "little" mice. Science 1986; 232: 511-2.

4. Lin C, Lin SC, Chang CP, Rosenfeld MG. Pit-1dependent expression of the receptor for growth hormone releasing factor mediates pituitary cell growth. Nature 1992; 360: 765-8.

5. Mayo KE. Molecular cloning and expression of a pituitary-specific receptor for growth hormonereleasing hormone. Mol Endocrinol 1992; 6: 173444.

6. Gaylinn BD, Harrison JK, Zysk JR, Lyons CE, et al. Molecular cloning and expression of a human anterior pituitary receptor for growth hormonereleasing hormone. Mol Endocrinol 1993; 7: 7784.

7. Kolakowski LF, Jr. GCRDb: a G-protein-coupled receptor database. Receptors Channels 1994; 2: 17.

8. Godfrey P, Rahal JO, Beamer WG, Copeland NG, et $a l$. GHRH receptor of little mice contains a missense mutation in the extracellular domain that disrupts receptor function. Nat Genet 1993; 4: 227-32.

9. Lin SC, Lin CR, Gukovsky I, Lusis AJ, et al. Molecular basis of the little mouse phenotype and implications for cell type-specific growth. Nature 1993; 364: 208-13.

10. Gaylinn BD, DeAlmeida VI, Lyons CE, Jr., Wu KC, et al. The mutant growth hormone-releasing hormone (GHRH) receptor of the little mouse does not bind GHRH. Endocrinology 1999; 140: 506674.

11. Baumann G, Maheshwari H. The Dwarfs of Sindh: severe growth hormone (GH) deficiency caused by a mutation in the GH-releasing hormone receptor gene. Acta Paediatr (Suppl) 1997; 423: 33-8.

12. Maheshwari HG, Silverman BL, Dupuis J, Baumann G. Phenotype and genetic analysis of a 
syndrome caused by an inactivating mutation in the growth hormone-releasing hormone receptor: Dwarfism of Sindh. J Clin Endocrinol Metab 1998; 83: 4065-74.

13. Wajnrajch MP, Gertner JM, Harbison MD, Chua $\mathrm{SC}, \mathrm{Jr}$., et al. Nonsense mutation in the human growth hormone-releasing hormone receptor causes growth failure analogous to the little (lit) mouse. Nat Genet 1996; 12: 88-90.

14. Netchine I, Talon P, Dastot F, Vitaux F, et al. Extensive phenotypic analysis of a family with growth hormone (GH) deficiency caused by a mutation in the GH-releasing hormone receptor gene. J Clin Endocrinol Metab 1998; 83: 432-6.

15. Wajnrajch MP, Gertner JM, Harbison MD, et al. Haplotype analysis of three kindreds with an identical (E72X) mutation in the growth hormone releasing hormone receptor gene. Program 81st Annual Meeting of the Endocrine Society, San Diego, CA 1999: 342.

16. Maheshwari HG, Baumann G. Genomic organization and structure of the human growth hormone releasing hormone receptor gene. Program 79th Annual Meeting of the Endocrine Society, Minneapolis, MN 1997: 156.

17. Salvatori R, Hayashida CY, Aguiar-Oliveira MH, Phillips JA III, et al. Familial dwarfism due to a novel mutation of the growth hormone- releasing hormone receptor gene. J Clin Endocrinol Metab 1999; 84: 917-23.

18. Aguiar-Oliveira MH, Gill MS, Barretto ES, Alcantara MR, et al. Effect of severe growth hormone (GH) deficiency due to a mutation in the
GH-releasing hormone receptor on insulin-like growth factors (IGFs), IGF-binding proteins, and ternary complex formation throughout life. J Clin Endocrinol Metab 1999; 84: 4118-26.

19. Hayashida CY, Gondo RG, Ferrari C, Toledo SP, et al. Familial growth hormone deficiency with mutated GHRH receptor gene: clinical and hormonal findings in homozygous and heterozygous individuals from Itabaianinha. Eur J Endocrinol 2000; 142: 557-563.

20. Salvatori R, Fan X, Phillips JA III, Espigares-Martin $\mathrm{R}$, et al. GHRH-receptor mutations account for a significant proportion of genetic causes of autosomal recessive isolated GH deficiency type IB. Program 82nd Meeting Endocrine Society, Toronto, Canada, 2000: 162.

21. DeAlmeida VI, Mayo KE. Identification of binding domains of the growth hormone-releasing hormone receptor by analysis of mutant and chimeric receptor proteins. Mol Endocrinol 1998; 12: $750-65$.

22. Horikawa R, Fujita K, Nakajima R, Gaylinn B, et al. A novel growth hormone-releasing hormone (GHRH) receptor mutation as a cause for isolated GH deficiency in a Japanese boy with severe short stature. Program 82nd Annual Meeting of the Endocrine Society, Toronto, Canada, 2000: 482.

23. Petersenn S, Schneider-Merck T, Luedecke D, Beil $\mathrm{FU}$, et al. Mutations of the growth hormonereleasing hormone receptor in somatotrophic pituitary adenomas. Program 82nd Annual Meeting Endocrine Society, Toronto, Canada, 2000: 162 . 